\title{
An Iridovirus from Bees
}

\author{
(Accepted 18 February 1976)
}

\begin{abstract}
SUMMARY
An iridovirus, Apis iridescent virus (AIV), isolated from sick adult specimens of Apis cerana (Hymenoptera) from Kashmir, closely resembles iridescent viruses from Tipula and Sericesthis spp. (TIV and SIV). However, AIV is only distantly related serologically to TIV and SIV and is even more remotely related to several other similar viruses that were tested in tube precipitation tests with intact particles. AIV multiplied in Apis mellifera, forming cytoplasmic iridescent crystalline aggregates in several tissues, but unlike all the other iridoviruses tested, it failed to multiply in Galleria mellonella.
\end{abstract}

Iridoviruses have been found occurring naturally in insects of the orders Diptera, Coleoptera and Lepidoptera (Kelly \& Robertson, 1973). We have recently isolated one from Hymenoptera, specifically from adult individuals of Apis cerana, the Eastern honey bee. Samples of these insects were sent to Rothamsted on two recent occasions, with an interval of nearly a year in between, from Kashmir, where they had become unusually inactive and had then died; affected colonies perished after about two months (D. B. Mahindre, personal communication). Almost all of the first sample of bees were infested with a parasitic mite resembling Acarapis woodi, which commonly infests the European honey bee, but the second sample was uninfested and neither sample contained other known parasites or microbial pathogens. However, both contained very many particles of an iridovirus, each bee yielding an average of $10^{10}$ to $10^{11}$ particles. We shall refer to this virus as $A$ pis iridescent virus (AIV).

Because of their symptoms, the bees of the first sample were examined for viruses, particularly for any resembling chronic bee-paralysis virus, by extracting the whole insects in a 4: I mixture of $0.0 \mathrm{I}$ M-potassium phosphate at $\mathrm{pH} 7.0$, containing $0.02 \%$ sodium diethyldithiocarbamate, and ethyl ether. The mixture was then emulsified with I vol. of carbon tetrachloride, coarsely filtered, cleared at $8000 \mathrm{~g}$ for $10 \mathrm{~min}$ and the cleared fluid centrifuged at $75000 \mathrm{~g}$ for $3 \mathrm{~h}$ (Bailey, Gibbs \& Woods, I968; Bailey \& Woods, 1974). No virus particles were seen in the final pellets, but the pellet from the clarification process was dark blue and contained many particles resembling those of an iridovirus. These particles were readily purified by alternate cycles of centrifugation at $1000 \mathrm{~g}$ for $30 \mathrm{~min}$ and $15000 \mathrm{~g}$ for $10 \mathrm{~min}$, which produced iridescent violet-blue pellets. The bees of the second sample were extracted similarly, omitting ethyl ether, with the same result.

The particles, approx. I $50 \mathrm{~nm}$ across, closely resemble those of Tipula iridescent virus. They contained DNA, as indicated by negative orcinol and positive diphenylamine reactions, and their sedimentation constant $\left(s_{20, w}\right)$ determined in a Spinco model $\mathrm{E}$ analytical centrifuge (Markham, I960), was 22I6S. Buoyant density determinations in caesium chloride, made in the Model E centrifuge after equilibration at $44000 \mathrm{rev} / \mathrm{min}$ for $17 \mathrm{~h}$ at $25^{\circ} \mathrm{C}$, showed four components with densities I·30, I·3I, I·32 and I·33 g/ml, each of which absorbed ultraviolet radiation. Subsequent determinations of buoyant densities, with virus freshly cultivated in adult or pupal individuals of the European honey bee, Apis mellifera (see below), gave one major and one minor component with densities of $1 \cdot 32$ and $\mathrm{I} \cdot 30 \mathrm{~g} / \mathrm{ml}$ 


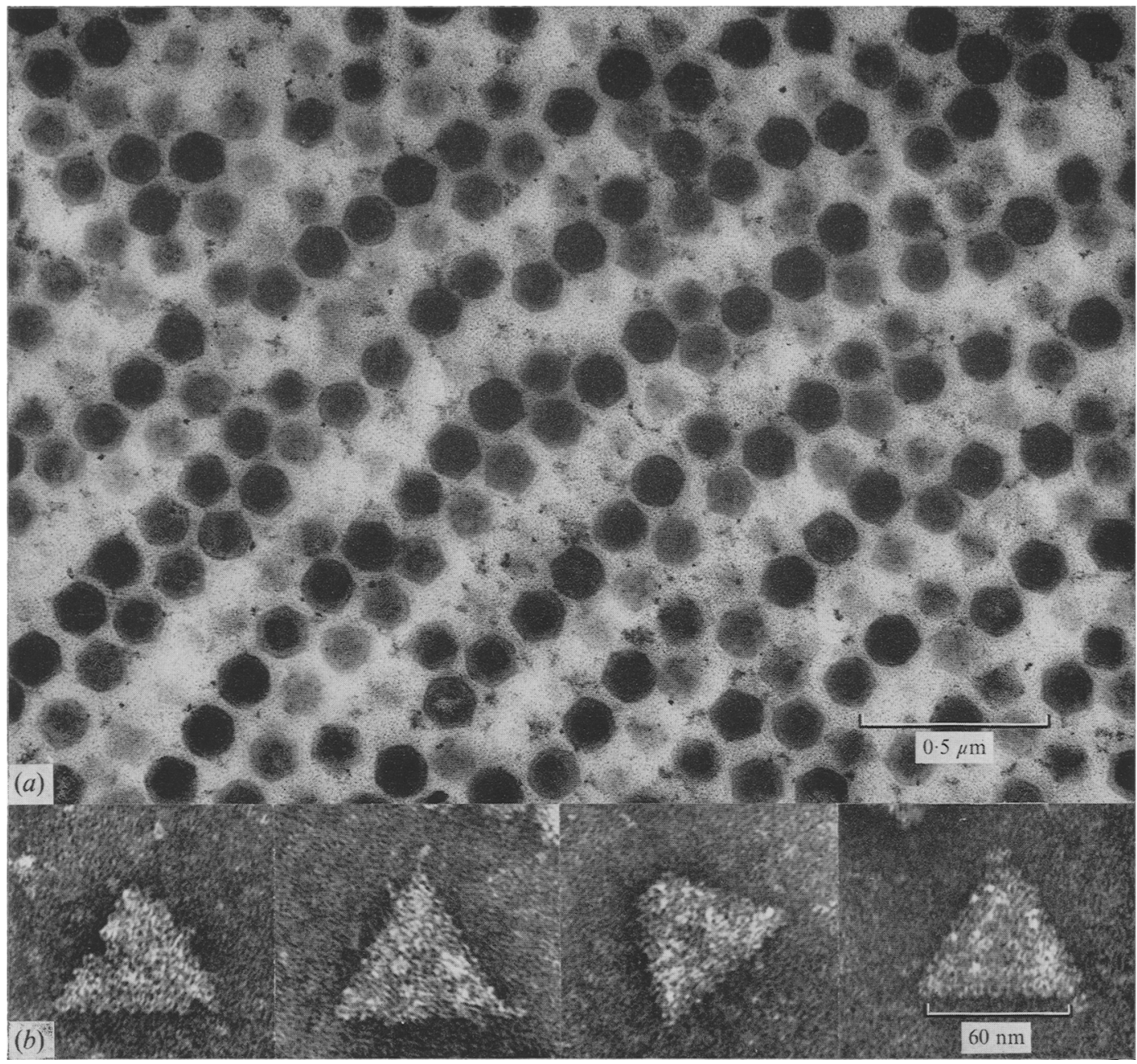

Fig. I. (a) Ultrathin section of part of the cytoplasm of a fat-body cell of Apis mellifera infected with Apis iridescent virus (AIV). (b) Trisymmetrons frcm AIV.

respectively. These may have represented 'full' and 'empty' particles, since some were penetrated by neutral sodium phosphotungstate to appear empty in the electron microscope. The other components in the virus preparations from the samples of $A$. cerana may have arisen from full and empty particles by the loss of regular fragments from the capsid, since some particles from $A$. mellifera were seen to be disintegrating spontaneously after prolonged storage in suspension. These produced isometric subunits $7 \mathrm{~nm}$ in diam. that were frequently arranged in trisymmetrons (Wrigley, 1969, 1970), with ten subunits per edge (Fig. I $b$ ), as in Tipula and Sericesthis iridescent virus particles.

An antiserum was prepared in a rabbit against a purified AIV preparation by giving one intramuscular injection of about $2 \times 10^{12}$ particles in $\mathrm{I} \mathrm{ml}$ of $0 . \mathrm{OI} \mathrm{M}$-potassium phosphate (optical density $/ \mathrm{cm}$ at $260 \mathrm{~nm}=54$, uncorrected for scatter) emulsified with an equal volume of Freund's complete adjuvant. The rabbit was bled at I4-day intervals and sera of highest titre ( $\mathrm{I} / 2048$ in tube precipitation tests) were obtained two and four weeks after in- 
jection. In tube precipitation tests, using AIV antiserum, Tipula, Sericesthis, Chilo, Wiseana and Opogonia iridescent viruses (TIV, SIV, CIV, WIV and OIV respectively) gave no reaction or reacted only weakly after $4 \mathrm{~h}$ at $37^{\circ} \mathrm{C}$, titres not exceeding, and usually being less than I/I 28 (SIV, TIV), I/8 (WIV and OIV) and I/4 (CIV). Absorption of AIV antiserum with TIV caused no detectable decrease of the homologous titre.

AIV multiplied when injected into adult individuals of Apis mellifera, forming cytoplasmic crystalline aggregates, especially in the fat-body and the hypopharyngeal glands (Fig. I $a$ ), which became a bright pale blue. It also multiplied when fed to young adult bees, the gut wall and proximal ends of the Malpighian tubules then becoming blue, in addition to the fat-body and hypopharyngeal glands; and it multiplied abundantly when injected into young pupae. These developed more slowly than pupae injected with water, but some occasionally matured into seemingly normal adults containing much virus.

AIV did not multiply when injected into larvae of Galleria mellonella, whether these were incubated at 20 or $30^{\circ} \mathrm{C}$, whereas all the other iridescent viruses mentioned above multiplied readily in these insects at $20^{\circ} \mathrm{C}$.

Clearly, AIV is well differentiated from other iridoviruses of the TIV-type; nevertheless, in physical details, it closely resembles this type and not that represented mainly by the mosquito iridescent viruses.

We thank Dr D. A. Govier, Rothamsted Experimental Station, for preparing antiserum, Dr J. F. E. Newman, Animal Virus Research Institute, Pirbright, for determining nucleic acid type, and Dr P. F. Dixon, NERC Unit of Invertebrate Virology, Oxford, for supplying WIV and OIV.

Rothamsted Experimental Station,

L. BAILEY

Harpenden, Herts., AL5 2JQ, England

BRENDA V. BALL

R. D. WoODS

\section{REFERENCES}

BAILEY, L. \& WOODS, R. D. (I974). Three previously undescribed viruses from the honey bee. Journal of General Virology 25, $175^{-1} 86$.

BAILEY, L., GIBBS, A. J. \& WOODS, R. D. (1968). The purification and properties of chronic bee-paralysis virus. Journal of General Virology 2, 25I-260.

KELLY, D. C. \& ROBERTSON, J. S. (I973). Icosahedral cytoplasmic deoxyriboviruses. Journal of General Virology 20, $17-24$.

MARKHAM, R. (I960). A graphical method for the rapid determination of sedimentation coefficients. Biochemical Journal 77, 516-5I9.

WRIGLEY, N. G. (1969). An electron microscope study of the structure of Sericesthis iridescent virus. Journal of General Virology 5, I23-I 34.

WRIGLEY, N. G. (1970). An electron microscope study of the structure of Tipula iridescent virus. Journal of General Virology 6, 169-173. 